\title{
PENGARUH KEBERADAAN PERUSAHAAN RITEL MODERN TERHADAP PENDAPATAN PEDAGANG HARIAN DI PASAR SYARIAH ULUL ALBAB DESA TANAH MERAH DAN PANDAU JAYA KECAMATAN SIAK HULU KABUPATEN KAMPAR
}

\author{
Lili Erti $^{1}$, Souvya Fitrie $^{2}$, Idel Waldelmi ${ }^{3}$ \\ Dosen tetap Fakultas Ekonomi Universitas Lancang Kuning \\ souvyafitrie@unilak.ac.id, lilierti@unilak.ac.id, \\ idelwaldelmi@unilak.ac.id
}

\begin{abstract}
Abstract This research background is based on the existence of modern retail located in shulah ulul albab market environment located between two red land villages and village of Pandau Jaya subdistrict Siak hulu Kampar regency. Based on the field data proves the income of sharia market traders after the existence of modern retail turned out to give effect with the drastic decline. This drastic decline occurred in the merchant's income between $1-3$ million, which reached the range of $3.33 \%(23.33 \%-20.00 \%)$ and followed by a decrease in revenues of more than 3 million originally reached $6.67 \%$ and after the presence of modern retail companies no more than 3 million merchant revenues. On the other hand, there is an increase in income to traders whose income is less than 1 million where the original $70 \%$ of trading partners earned less than 1 million to increase to $80 \%$ or increase by $10 \%$ from previous earnings. To prove scientifically the effect of modern retail presence on merchant's income on syariah market can be used a strongitative approach by using statistic through different test with $t$ test formula. Based on the results of the data with the application of the assumption is changes and no reduction before and after the existence of modern retail using dummy data, among others, the value of zero (0) which means no change and the value of one (1) which means the change. Survey conducted to 30 traders are eksedental that is when they are sale and purchase transactions in the sharia market ulul albab
\end{abstract}

Keywords: Revenue, Sharia Market and Modern

\section{PENDAHULUAN}

Persaingan bisnis merupakan konsekuensi dari pada para pelaku usaha, tidak terkecuali perdagangan ritel di Indonesia. Persaingan bisnis ritel ini membelah menjadi dua blok, yang pertama blok ritel tradisional yang secara langsung diwakili oleh toko kelontong serta yang kedua adalah ritel modern yang di wakili minimarket seperti Indomart, Alfamart, Planet Swalayan dan lain sebagainya.

Penyebab terjadinya persaingan antara pedagang harian/ kelontong dengan minimarket adalah karena keduanya memiliki kesamaan, keduanya sama-sama menjual kebutuhan seharihari, dari segi komoditas dua ritel ini mempunyai kemiripan hanya model pelayanan dan fasilitas yang berbeda. Menurut Kottler dalam mengklasfikasikan jenis pengecer salah satunya adalah toko kelontong yaitu toko yang pada umumnya berukuran relatif kecil dan terletak di daerah pemukiman, dengan jam buka yang panjang, serta menjual lini produk kebutuhan sehari hari (convenience) yang terbatas dengan tingkat perputaran yang tinggi (Philip Kotler, 2009: 141).

Menjamurnya minimarket pada satu sisi, menunjukkan perkembangan perekonomian yang bagus. Pertumbuhan minimarket hingga ke daerah-daerah merupakan eksen dari kemajuan perekonomian Indonesia secara makro. Namun di sisi lain, gairah ekonomi itu ternyata memicu keresahan dikalangan pedagang kelontong. Kehadiran ritel 
Jurnal Ilmiah Ekonomi dan Bisnis

Vol. 15. No.1, Maret 2018: 25-33

EISSN : $2442-9813$

ISSN : $1829-9822$

modern tersebut telah memunculkan iklim persaingan yang tidak sehat yang merugikan pedagang kelontong. Tidak menutup kecemburuan sosial di antara para pelaku usaha. Membuat pedagang kelontong khususnya merupakan pedagang dengan modal terbatas, kondisi usaha semakin terpuruk bahkan bisa mati, menurut Sekjen APPSI pertumbuhan minimarket pada satu titik lokasi otomatis mematikan minimal 20 warung masyarakat sehingga menurut Yusup sikumbang "jika izin pendirian terus di keluarkan maka kelangsungan hidup masyarakat paling bawah akan punah"(http://www.riauterkini.com).

Penataan tersebut di harapkan peran pemerintah dapat menjaga stabilitas pasa tradisional. Namun demikian bukan berarti setelah dikeluarkan perpres tersebut telah sesuai dengan apa yang diaharapkan karena masih ada toko modern yang yang menjadi masalah bagi pedagang kelontong seperti yang akan diteliti penulis.

Dari latar belakang diatas penulis ingin Melakukan sebuah penelitian di sebuah pasar di Kecamatan Siak Hulu desa tanah merah dan pandau jaya yang bernama pasar syariah ulul albab dimana sekitar pasar tersebut terdapat bangunan Indomaret, alfamar, Planet swalayan dan swalayan lainnya dengan beberapa meter saja yaitu kurang dari batas minimal 1.000 meter seperti yang telah ditetapkan ditetapkan pemerintah Kabupaten Kampar (http://disperindag.kabupatenkampar.go. id)

Sedangkan di pasar tersebut terdapat pedagang-pedagang kelontong yang menjual komoditi seperti apa yang ada di toko ritael sehingga menurut peneliti keberadaan Alfamart dan Indomaret tersebut berpotensi mempengaruhi pendapatan pedagang kelontong.

\section{TINJAUAN PUSTAKA}

Sinaga (2006) dalam penelitian Endi Sarwoko, menyatakan bahwa pasar modern adalah pasar yang dikelola dengan manajemen modern, umumnya terdapat di kawasan perkotaan, sebagai penyedia barang dan jasa dengan mutu dan pelayanan yang baik kepada konsumen (umumnya anggota masyarakat kelas menengah ke atas). Pasar modern antara lain mall, supermarket, departement store, shopping centre, waralaba, minimarket, swalayan, pasar serba ada, toko serba ada dan sebagainya. Barang yang dijual memiliki variasi jenis yang beragam. Selain menyediakan barang-barang lokal, pasar modern juga menyediakan barang impor. Barang yang dijual mempunyai kualitas yang relatif lebih terjamin karena melalui penyeleksian terlebih dahulu secara ketat sehingga barang yang rijek/tidak memenuhi persyaratan klasifikasi akan ditolak. Secara kuantitas, pasar modern umumnya mempunyai persediaan barang di gudang yang terukur. Dari segi harga, pasar modern memiliki label harga yang pasti (tercantum harga sebelum dan setelah dikenakan pajak).

$$
\text { Hasil analisis Important }
$$

Perormance dan Analysis bahwa preferensi konsumen untuk memilih warong sebagai tempat berbelanja dikarenakan kepuasan mereka terhadap jangkauan harga yang rendah.Sedangkan untuk konsumen yang lebih memilih berbelanja di minimarket adalah karena keragaman barang yang diberikan oleh minimarket lebih banyak pilihan sehingga membuat preferensi masyarakat lebih memilih berbelanja ke minimarket. Berdasarkan jangkauan pelayanan, dapat diketahui bahwa semakin besar jangkauan minimarket, maka akan semakin banyak toko yang terfriksi dengan jankauan pelayanannya. Rata-rata satu minimarket berdampak terhadap 5 warong berkaitan jarak jangkauan pelayanan.Berdasarkan penelitian, semakin jauh warong terhadap 
minimarket, pengaruh yang ditimbulkan semakin kecil.Namun, semakin dekat warong dengan minimarket maka pengaruhnya semkain besar terjadi pada jumlah konsumen yang dating setiap harinya (wibowo, rengkung, 2012).

\section{METODE PENELITIAN}

Metode yang digunakan dalam penelitian ini adalah metode penelitian deskriptif kuantitatif. Menurut Nawawi (2003 : 64) metode deskriptif yaitu metode -metode penelitian yang memusatkan perhatian pada masalahmasalah atau fenomena yang bersifat aktual pada saat penelitian dilakukan, kemudian menggambarkan fakta-fakta tentang masalah yang diselidiki sebagaimana adanya diiringi dengan interprestasi yang rasional dan akurat.

Penelitian ini menggunakan pendekatan Lapangan, dilakukan kepada kepada Pedagang Harian yang melakukan Transaksi jual beli di pasar Syariah Ulul Albab.

Populasi dalam penelitian ini adalah pedagang pasar syariah ulul albab. Saat ini pedagang harian berjumlah 50 Padagang. Oleh karena relative banyaknya jumlah populasi maka diambil sampel secara proposional random sampling menggunakan skala likert, sebagaimana berikut : $\mathrm{n}=\mathrm{N} / \mathrm{N} \mathrm{e}^{2}+1 \quad$ (Riduwan, 2008:49) dimana :

$\mathrm{n}=$ Jumlah sampel

$\mathrm{N}=$ Jumlah Populasi

$\mathrm{E}^{2}=\%$ Tingkat kesalahan dalam pengambilan sampel atau batas toleransi kesal ahan $(10 \%)$

$\frac{50}{1+50(0.1)}{ }^{2}=\frac{50}{1+0}=33,3 / 34$

Jadi populasi dalam penelitian ini terdiri atas pedagang, pengelola pasar dan toko modern/ ritel yang berjumlah 34 sample. Dalam suatu penelitian, peneliti harus menentukan metode apa yang akan digunakan untuk mengumpulkan data dalam rangka menjawab masalah penelitian. Metode penelitian pengumpulan data yang digunakan adalah kuesioner, metode interview (wawancara), metode observasi dan metode dokumentasi

Metode yang digunakan dalam penelitian ini adalah metode penelitian deskriptif kuantitatif. Menurut Nawawi (2003 : 64) metode deskriptif yaitu metode -metode penelitian yang memusatkan perhatian pada masalahmasalah atau fenomena yang bersifat aktual pada saat penelitian dilakukan, kemudian menggambarkan fakta-fakta tentang masalah yang diselidiki sebagaimana adanya diiringi dengan interprestasi yang rasional dan akurat. Untuk membuktikan secara ilmiah pengaruh keberadaan ritel modern terhadap pendapatan pedagang pada pasar syariah dapat digunakan pendekatan kuatitatif dengan menggunakan statistik melalui uji beda dengan rumus $t$ test.

\section{HASIL DAN PEMBAHASAN}

Deskripsi pendapatan padagang pasar syariah setelah adanya keberadaan ritel modern ternyata memberikan pengaruh dengan terjadinya penurunan yang drastis. Penurunan drastis ini terjada pada pendapatan pedagang antara $1-3$ juta yang mencapai kisaran angka 3,33\% ( $23.33 \%-20.00 \%$ ) dan di ikuti dengan penurunan pada pendapatan yang lebih dari 3 juta semula mencapai angka $6.67 \%$ dan setelah keberadaan perusahaan ritel modern tidak ada pendapatan pedagang yang lebih dari 3 juta.

Namun sebaliknya terjadi peningkatan pendapatan pada pedagang yang pendapatanya kurang dari 1 juta dimana semula $70 \%$ padagang berpengasilan kurang dari 1 juta menjadi meningkat menjadi $80 \%$ atau meningkat sebesar $10 \%$ dari penghasilan sebelumnnya.

Apabila dianalisa penurunan pasca keberadaan ritel modern itu disebabkan 


\section{Jurnal Ilmiah Ekonomi dan Bisnis}

Vol. 15. No.1, Maret 2018: 25-33

EISSN : $2442-9813$

ISSN : $1829-9822$

oleh beberapa masalah yang lumrah dihadapi antara lain yang dapati dan dijelaskan pada ulasan berikut :

Dengan adanya indomaret pendapatan menurun. Keberdaan perusahaan ritel memberikan dampak yang luar biasa terhadap pendapatan pedagang khususnya pedagang pasar syariah yang terletak desa tanah merah kecamatan siak hulu kabupaten Kampar. Hal ini dapat dilihat dari survey yang telah dilakukan melalui sebaran kuisioner dan wawancara pada pedagang pasar syariah ulul albab. Pedagang kelontong dengan segala keterbatasanya baik dari segi tempat, financial, kenyamanan dan lainnya dan perusahaan ritel dengan segala kelebihannya baik secara financial maupun tempat serta pelayanan. Sebagai pedagang bagi mereka mampu bertahan saja sudah cukup. Persaingan dunia usaha memang memberikan nilai tersendiri bagi pedagang baik persaingan dengan perusahaan skala besar ritel modern, dengan sesama pedagang dan lainnya. Barang yang dijualpun baik pedagang, perusahaan ritel dimana barang yang dijual hampir sama barang yang dijual tersebut. Hal inilah yang menyebabkan persaingan itu muncul dan memberikan pengaruh terhadap pendapatan pedagang pasar syariah.

Waktu operasional terbatas, kebersihan tempat dan sistem pengambilan barang dari agen. Pasar syariah yang terletak di desa tanah merah kecamatan siak hulu kabupaten Kampar memilki waktu operasional yang terbatas, walaupun pasar syariah berada pada posisi yang strategis dan di pinggir jalan, karena waktu operasional yang terbatas ini juga menjadi yang dikeluhkan oleh pedagang pasar syariah Beda dengan perusahaan ritel yang waktu operasionalnya hampir 24 jam setiap harinya. Dari segi kebersihan tempat antara pasar syariah dan ritel moden jauh lebih bersih ritel modern tersebut, hal ini bisa dilihat dan dibedakan ketika berbelanja baik di pasar maupun ritel modern tersebut. Kebersihan memang menjadi kendala tersendiri dari pengelola pasar karena banyaknya yang akan dibersihkan dan ditambah di mana semuanya masih serba tradisional. Sistem pengambilan barang dari agen bagi pedagang semuanya di beli dengan serba sedikit, perputaran barang juga lambat, modal yang terbatas dan lainnya, berbeda dengan perusahaan ritel hampir setiap hari barang yang datang dengan mobil membawa barang yang bervariasi dan dengan jumlah yang banyak serta lebih terjamin kualitasnya.

Barang yang dijual sama dengan ritel modern (Indomaret dan alfamart) dengan pedagang. Dari segi barang yang dijual oleh padagang kelontong pasar syariah hampir semuanya sama baik dari segi makanan, minuman dan lainnya. Ritel modern memang menjual barang yang sama dengan pedagang pasar syariah namun ada yang berbeda seperti halnya menjual token listrik, pulsa, BPJS, dan angsuran kredit lainnya. Kesamaan inilah yang menyebabkan pedagang tidak mampu bersaing dengan ritel modern yang memiliki kemampuan yang jauh lebih baik di bandingka dengan pedagang eceran. Kondisi ini semakin membuat pedagang tidak mampu bersaing dengan ritel modern yang lokasi yang juga berdekatan satu sama lainnya.

Omset menurun karena perusahaan ritel sering mengadakan promo/ diskon Penurunan omset dalam transaksi bisnis. memang suatu pilihan dan merupakan suatu hal yang wajar dengan kondisi persaingan dunia bisnis, baik sekala besar, menengah dan kecil. Namun menjadi tidak wajar dengan persaingan dunia usaha/ bisnis yang tidak sehat, di mana persaiangan ini berlangsung tanpa peduli dengan dunia usaha yang ada di sekitarnya seperti hal yang terjadi pada pedagang kelontong pasar syariah. Kalau dilihat dengan seksama memang 
persaingan itu luar biasa hebatnya seperti halnya ritel modern memberikan potongan harga/ diskon kepada konsumen dengan berbagai merek dagang yang sama dijual oleh padagang kelontong, potongan harga itu dilakukana dengan cara berkelanjutan dan terus menerus dan dilokasi yang berada di keramaian yaitu pasar itu sendiri. Persaingan bisnis yang tidak berimbang akan menimbulkan permasalahan pada pedagang yang memilki modal yang terbatas dan akan berimbas pada tidak bisa melanjutkan usaha atau tutup karena antara pendapatan dan pengeluaran yang tidak berimbang. Oleh karenanya alangkah baiknya ada peran pemerintah dalam upaya bagaimana melindungan usaha usaha kecil.

Harga yang rendah dari pasar, waktu pelayanan ritel 24 jam dan dipasar hanya setengan hari. Persaingan harga memang menjadi permasalahan yang mendasar antara pedagang dan konsumen, dimana bisa dilihat dari kecendrungan konsumen yang selalu membandingkan harga antara pedagang pasar syariah dengan ritel modern yang berada di sekitar pasar syariah tersebut. Memang disatu sisi tidak semua barang yang dijual dipasar lebih mahal dibandingkan dengan ritel modern begitu juga dengan sebaliknya. Waktu pelayanan yang terbatas bagi pedagang pasar dari waktu hingga siang hari hari dari jam 05.00 pagi hingga 13.00 atau lebih, namun konsumen sudah sepi begitu juga pedagang jam 13.00 sudah ada yang tutup. Beda dengan ritel modern yang pelayanannya 24 jam dan sistem bergantian ditambah dengan pelayanan yang bagus, nyaman, dan bersih, inilah yang menjadi daya Tarik bagi konsumen untuk beralah berbelanja dari pasar tradisonal ke pasar modern. Jadi persaingan antara pedagang dengan ritel moden tidak hanya hanya bersaing dengan harga tapi juga bersaingan dengan waktu operasional serta waktu pelayanan terhadap konsumen yang menginginkan barang yang ingin dibeli bisa didapatkan kapan saja.

Konsumen yang beralih ke indomaret/alfamart dalam berbelanja yang padahal dahulunya pelanggan. Membangun emosional dengan pelanggan memang sangat penting karena pelanggan adalah asset yang perlu dirawat dan dijaga, dengan mampu membangun kedekatan secara emosional dengan pelanggan memang pilihan paling penting agar pelanggan tidak berpindah kepada penjual yang lain. Biasanya pedagang yang mampu menjalin hubungam emosional denga pelanggan berapa pun murahnya barang yang dijual oleh pedagang/ritel lainnya tidak akan mempengaruhi pelanggan untuk berpindah membeli barang ke tempat lainnya kecuali memang barang yang dijual tersebut tidak ada/ habis. Kontek harga yang murah memang memiliki daya tarik tersendiri bagi konsumen dalam berbelanja untuk kebutuhan hariannya. Oleh karenanya penting sekali bagaimana menjaga pelanggan, perlu juga diketahui bahwasannya dengan terbangunnya kedekatan dengan pelanggan, pedagang bisa saling bertukar pikiran, saling membantu baik ketika pelanggan lagi kekurangan uang alias bisa memberi hutang/ sebaliknya dan saling bertanya kabar berbeda dengan ritel modern yang cendrung hanya sebatas berbalanja dan saling tidak mengenal antara satu sama lainnya. Dengan demikian yang namanya pelanggan tidak akan berpindah hati / berpinh untuk berbelanja.

Untuk membuktikan secara ilmiah pengaruh keberadaan ritel modern terhadap pendapatan pedagang pada pasar syariah dapat digunakan pendekatan kuatitatif dengan menggunakan statistik melalui uji beda dengan rumus $\mathrm{t}$ test. Berdasarkan hasil olah data dengan penerapan asumsi bahwasannya perubahan dan tidak terjadi penguragan 


\section{Jurnal Ilmiah Ekonomi dan Bisnis}

Vol. 15. No.1, Maret 2018: 25-33

EISSN : $2442-9813$

ISSN : $1829-9822$

sebelum dan sesudah keberadaan ritel modern dengan menggunakan data dummy antara lain nilai nol (0) yang artinya tidak ada perubahan dan nilai satu (1) yang artinya adanya perubahan. Survey yang dilakukan kepada 30 orang pedagang secara eksedental yakni pada saat mereka melalukan transaksi jual beli di pasar syariah ulul albab. Diperoleh informasi sebagai berikut :

Keberadaan $\mathrm{r}$ One-Sample Test

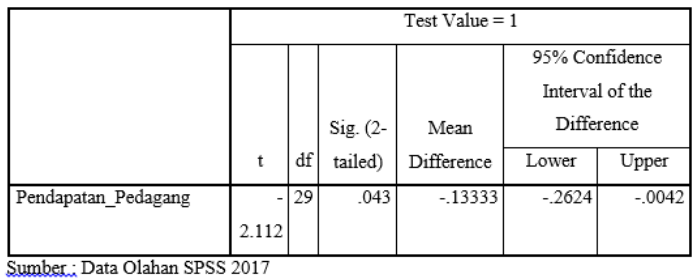

Dari tabel tersebut dapat diketahui bahwa nilai uji beda yang berhasil diperoleh yakni sebesar nilai $\mathrm{t}=-2.112$ dan angka ini apabila di bandingkan dengan nilai $t$ table pada alpha $=0.05$ maka t table sebesar -2.042. Angka ini apabila dibandingkan dengan nilai $t$ hitung menunjukkan bahwa minus $t$ hitung lebih kecil dari minus t table ( $2.112<-2.042)$ ini menunjukkan bahwasannya terbukti bahwa terdapat pengaruh yang significant keberdaan ritel modern terhadap pendapatan pedagang kelontong pada pasar syariah. Angka ini juga untuk lebih mudahnya dapat dilihat pada $\mathrm{P}$ value 0.043 yang lebih kecil dari ambang toleransi 0.005 $(5 \%)$.
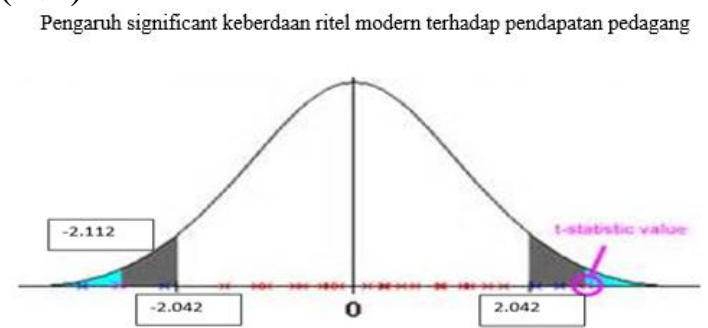

Faktor Penghambat dalam penelitian ini antara lain: Cuaca, operasional pasar, dan gajian, kebersihan pasar yang kurang dan operasional pasar yang tidak sampai sore Kondisi alam (Cuaca) hujan memang suatu yang tidak dihindari melainkan suatu yang harus di syukuri. Memang dengan kondisi hujan konsumen lebih cendrung tidak keluar rumah dan berbelanja di tempat terdekat dengan rumah dan pastinya akan berimbas pada pada pedagang yang ada di pasar syariah, operasional pasar yang juga terbatas tidak sampai 24 jam namun hanya sampai jam 13.00 atau lebih. Itupun hanya kebanyakan dari kalangan pedagang sendiri dan kondisi pasar ini juga bergantung pada cepat atau lambatnya konsumen gajian, karena kondisi pasar yang kebanyakkan pelanggan berasal dari sekitar dua desa yaitu desa tanah merah dan desa pandau jaya dan kebanyakan perumahan. Kebersihan yang dikeluhkan oleh pedagang juga bisa menjadi pelihan oleh konsumen untuk enggan berbelanja ke pasar syariah apalagi di tambah dengan kondisi hujan. Oleh karenanya penting sekali menjadi acuan bagi pengelola pasar dan pedagang untuk senantiasa mengedapankan sikap untuk bisa menjaga kebersihan, memperhatikan keinginan pedagang untuk memastikan bisa memberikan rasa aman baik dengan kondisi cuaca huja, jam operasional lebih diperhatikan agar pelanggan tetap nyaman berbelanja ke pasar syariah serta pedagang yang ada di pasar syariah tidak mengeluh dan tetap senantiasa mengedepankan rasa syukur kepada yang mengatur rejeki dan berupaya menerapkan konsep sistem jual beli sesuia syariat Islam.

Keamanan pasar. Memberikan rasa aman pada konsumen menjadi sangat penting karena rasa aman akan menimbulkan kepercayaan kepada konsumen untuk berbelanja, kenyataan ini memang menjadi alasannya, baik pedagang dan konsumen dalam berbelanja di pasar syariah. Rasa aman membuat konsumen akan datang lagi berbelanja dan rasa tidak nyaman akan membuat pelanggan enggan untuk datang berbelanja. Berbeda dengan ritel moder yang tidak hanya memperhatikan dari sisi harga, pelayanan, 
tempat, kebersihan namun juga memperhatikan rasa aman/ kenyaman kepada konsumen yang datang berbelanja seperti halnya adanya kamera CCTV yang terpasang disetiap sudut. Alasan inilah yang seharusnya diperhatikan oleh pengelola pasar agar keamanan pasar yang ada di pasar syariah perlu di perhatikan agar dapat pasar syariah memberikan daya saing dan daya Tarik tersendiri bagi pelanggan dalam berbelanja di pasar syariah.

Pembeli sepi dan pengeluaran banyak. Hal inilah sudah menjadi phenomena bagi pedagang yang akan berhadapan dengan konsumen sepi. Pembeli yang sepi atau sedikit suatu yang hal yang biasa karena bagaimana mungkin konsumen akan berbelanja ke pasar sementara kebutuhan sudah penuhi untuk satu bulan, belum gajian/ pendapatan sedikit, kebutuhan akan yang lainnya bertambah seperti pendidikan, traveling dan lainnya maka tidak heran akan menjumpai konsumen yang sepi ke pasar untuk berbelanja, itupun kalau ke pasar hanya untuk membeli sayur sayuran atau sekedar kepasar saja dan kebutuhan akan pedagang juga sama dengan konsumen lainnya kalau pasar sepi otomatis pendapatan berkurang sementara yang namanya kebutuhan pedagang juga bertambah, jadi kalau pendapatan berkurang otomatis juga akan berdampak pada modal dari pedagang yang berujung tidak mampu bersaing, bertahan dalam usaha dan tutup.

Modal yang terbatas, pelanggan yang tidak tetap serta mencari harga yang murah. Persaiangan harga, baik dengan sesama pedagang, ditambah dengan perusahaan ritel. Pembeli lebih dominan berbelanja ke indomaret dibanding ke pasar dan di indomaret bebas parker sedangkan di pasar syariah di kenakan biaya parker. banyaknya konsumen yang komplain mengenai harga, karena di bandingkan dengan ritel

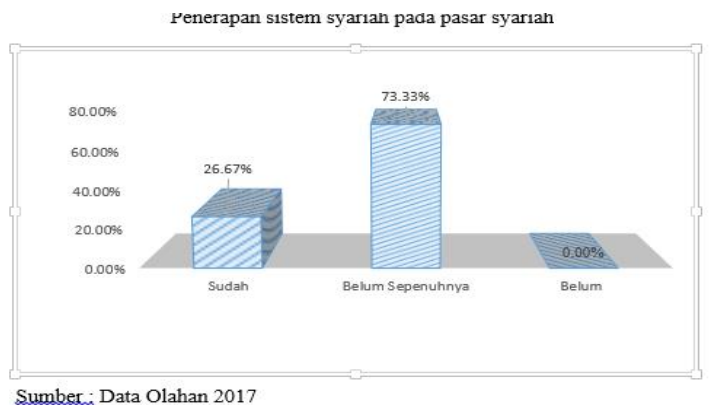

Dari gambar tersebut berkaitan dengan penerapan syariah pada pasar syariah diberikan tanggapn dafrip pedagang yang melaksanakan kegiatan jual beli menunjukkan bahwa hanya 26,67\% pedagang yang menerapkan sistem syariah sedangkan sisanya sebesar 73.33 sudah menerapakan tetapi belum sepenuhnya.

Hasil waacara dengan pengelola pasar dengan adanya persaingan antara perusahaan ritel dengan pedagang eceran di pasar syariah dalam merebut konsumen/ pangsa pasar, menyebutkan bahwa perusahaan ritel senantiasa mengadakan promo dan diskon walaupuan dengan beberapa produk tertentu, mengambil barang dalam jumlah besar, sedangkan pedagang mengambil/membeli barang dengan jumlah yang terbatas dan jumlah modal yang juga terbatas serta ditambah dengan tidak adanya pedagang yang memberikan diskon/potongan harga seperti halnya yang dilakukan oleh perusahaan ritel. Dengan keberaadan perusahaan ritel di sekitar lingkungan pasar juga memberikan pengaruh yang negative dengan terjadinya penurunan pendapatan serta banyaknya complain dari pelanggan ke pedagang dan ditambah dengan jam operasional pasar yang hanya sampai siang walaupun ada sebagian pedagang yang buka sampai sore, kebersihan pasar yang belum sepenuhnya bersih dan parkiran yang masih berbayar, sedangkan perusahaan ritel buka hingga 24 jam, tempat yang nyaman, bersih dan bebas parkir serta walaupun kadang kadang adanya 


\section{Jurnal Ilmiah Ekonomi dan Bisnis}

Vol. 15. No.1, Maret 2018: 25-33

EISSN : $2442-9813$

ISSN : 1829-9822

pelanggan yang komplain akan harga yang tertera di rak - rak dagangan dengan struk belanja.

Perusahan ritel dengan segala kekuatan yang dimiliki, baik financial, SDM, trust, lokasi dan lainnya yang menyebabkan perusahaan ritel seperti indomaret dan alfamart mampu menangkap keinginan pelanggan dengan segala perkembangan zaman dan teknologi. Perusahaan ritel (indomaret dan alfamart) yang berdiri baru tiga tahun dilingkungan pasar syariah memberikan efek yang luar biasa (Negative) dengan izin yang diberikan oleh pemerintah daerah (Kampar) memiliki peluang usaha yang mampu bersainga baik dari segi harga, pelayanan, tempat dan produk dan tidak maunya perusahaan ritel tidak mau bermitra dengan pedagang pasar syariah.

\section{KESIMPULAN DAN SARAN}

Pengaruh keberadaan perusahaan ritael terhadap pendapatan pedagang kelontong di pasar syariah ulul albab di desa tanah merah dan desa pandau jaya kecamatan siak hulu kabupaten Kampar, Setelah dideskripsikan mengenai pendapatan pedagang kelontong pada pasar syariah pasca keberadaan ritel modern cendrung mengalami penurunan.

Upaya yang dilakukan oleh pedagang kelontong pasar syariah ulul albab di desa tanah merah dan desa pandau jaya kecamatan siak hulu kabupaten Kampar dalam menghadapi persaingan dengan perusahaan retail tersebut, dengan Pedagang belum sepenuhnya menerapkan sistem syariah pada pasar syariah sehingga menyebabkan Pendapatan terus menurun karena tidak mampu mengimbangi keberaddan ritel modern yang lebih bersih dan harga lebih pasti serta menyediakan barang yang sesuai kebutuhan konsumen sedangkan pada pasar syariah yang semesstinya kebersihan sebagian dari iman masih belum diterapkan, keamanan tidak terjamin padahal berada pada pasar syariah yang menyatakan mencuri adalah perbuatan yang dilarang dan penerapan harga oleh pedagang tidaks sesuai dengan sunnah rasulullah.

Pemerintah perlu meninjau ulang pemberian izin ritel modern karena memberikan pengaruh negatif yakni terjadinya penurunan pendapatan pedagang kelontong pada pasar syariah dan Pedagang perlu menerapakan sistem jual beli syariah dalam mempertahankan konsumen

\section{DAFTAR PUSTAKA}

Aramiko, S. A. (2011). Dampak Pasar Ritel Modern Terhadap Pasar Dan Pedagang Ritel Tradisional Di Kota Tangerang Selatan Dan Upaya Penanggulangannya.

Pratama, P. Danu. (2015). Analisis Pengaruh Harga Dan Pelayanan Terhadap Keputusan Membeli Di Pasar Tradisional(Studi Pada Pasar Tradisional Jaten Di Daerah Jaten) Vol .03 No, 1-5.

eka Yuliasih. (2013). No Title. Studi Eksplorasi Dampak Keberadaan Pasar Modern Terhadap Usaha Ritel Waserda Dan Pedagang Pasar Tradisional Di Kecamatan Klirong Kabupaten Kebumen, Vol. 3 No., 78-79.

Hasanah, U., \& Winarwati, I. (2011). Studi Potensi Kompetisi Antara Pasar Tradisional Dengan Toko Modern Pasca Peraturan Presiden ( Perpres ) Nomor 112 Tahun $2007 \mathrm{Di}$ Madura , 236-247.

Https://Id.Wikipedia.Org/Wiki/Eceran

\begin{tabular}{cllll} 
Intruksi & Presiden & No. 10 & Tahun & 1999 \\
\hline & Tentang Pemberdayaan & Usaha \\
\hline Menengah & &
\end{tabular}


Keputusan Menteri Keuangan No. 40 /KMK.06/2003 Tentang Pendanaan Kredit Usaha Mikro Dan Kecil

Peraturan Menteri Perdagangan No. 53/M-DAG/PER/12/2008

Tentang Pedoman Penataan Dan Pembinaan Pasar Tradisional, Pusat Perbelanjaan Dan Toko Modern

Peraturan Menteri Perdagangan No.12 Tahun 2006 Tentang Waralaba

Maria, A., \& Anggraini, T. (2014). Peranan Industri Kecil-Menengah Dalam Pembangunan Ekonomi Indonesia : Ditinjau Dari Perspektif Hukum Persaingan Usaha, Xiii(3), 441-467.

Fuyi, Nadya. (2014). Analisis Tanggapan 4 Toko Tradisional Pada Waralaba Indomaret/Alfamart (Toko Modern) Di Area Kampus Universitas Jember., Vol. $02 \mathrm{No}$, 2-3.

Nashirudin. (2012). Dampak Keberadaan Indomaret Terhadap Pendapatan Pedagang Kelontong Di Pasar Cuplik Kecamatan Sukoharjo. Manajemen \& Agribisnis, 11(2), 119-128.

Sarwoko, Endi, 2008. Dampak Keberadaan Pasar Modern Terhadap Kinerja Pedagang Pasar Tradisional Di Wilayah Kabupaten Malang. Jurnal Ekonomi Modernisasi Malang.

Sukirno, Sadono, 2015. Mikro Ekonomi Teori Pengantar. Jakarta. PT. Raja Grafindo Persada.Edisi Ketiga.
Wibowo, Rengkung, M. (2012). Wibowo,Rengkung, Mastutie. Water, Vol 1 No, 114-121.

Zahratain, I., \& Anggraeni, L. (2015). Dampak Perkembangan Toko Modern Terhadap Kinerja Pedagang Produk Pertanian Pada Pasar Tradisional Di Kota Bekasi. Jurnal 